\title{
What makes political authorities legitimate? Students' ideas about legitimacy in five European democracies and hybrid regimes
}

\section{Honorata Mazepus}

To cite this article: Honorata Mazepus (2017) What makes political authorities legitimate? Students' ideas about legitimacy in five European democracies and hybrid regimes, Contemporary Politics, 23:3, 306-327, DOI: 10.1080/13569775.2017.1306762

To link to this article: https://doi.org/10.1080/13569775.2017.1306762

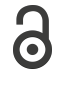

(c) 2017 The Author(s). Published by Informa

UK Limited, trading as Taylor \& Francis Group

\section{+ View supplementary material ๘}

\section{Published online: 24 Mar 2017.}

Submit your article to this journal $\longleftarrow$

Џlll Article views: 2473

View Crossmark data ¿

Citing articles: 2 View citing articles $\longleftarrow$ 


\title{
What makes political authorities legitimate? Students' ideas about legitimacy in five European democracies and hybrid regimes
}

\author{
Honorata Mazepus \\ Institute of Public Administration, Leiden University, Leiden, Netherlands
}

\begin{abstract}
Because the legitimacy of political authorities exists only in the eyes of citizens, this study investigates which criteria citizens use to decide that an authority is legitimate. By comparing ideas about what makes political authorities legitimate, this study in five European democracies and hybrid regimes illuminates the 'demand side of political legitimacy'. Using original student survey data, this article compares expectations of students from the Netherlands, France, Poland, Ukraine, and Russia about how political authorities should acquire the right to rule and how they ought to behave when in office. The analysis shows that the respondents across the five countries use similar criteria for granting legitimacy. Across the five countries, throughput and input were more important criteria for legitimacy than the output produced by authorities. Although several country differences were found, these differences did not align with regime type. The findings challenge the widespread view that what kind of authorities people consider legitimate is determined by their socialization in a particular political regime.
\end{abstract}

\section{KEYWORDS}

Legitimacy beliefs; hybrid regimes; democracy; comparative politics; citizens' expectations; Russia; Ukraine

\section{Introduction}

What makes political authorities legitimate in the eyes of citizens? How can political elites engender legitimacy? These are the central questions in studies of political legitimacy across different regimes. Earlier works concerned with the legitimacy of authoritarian regimes emphasized the role of performance - delivery of good living standards and goal-achievement in general - in convincing citizens about the authorities' right to rule. (e.g. Holmes, 1993; di Palma, 1991, p. 57; Rigby \& Fehér, 1982, pp. 10-11; White, 1986). A growing body of recent scholarship shows that leaders and elites in non-democratic regimes use a broad array of justifications to stay in power and engender legitimacy among citizens (e.g. Holbig \& Gilley, 2010; Mazepus, Veenendaal, McCarthy-Jones, \& Trak Vásquez, 2016; Morgenbesser, 2016; Omelicheva, 2016; Sandby-Thomas, 2014; Von

CONTACT Honorata Mazepus h.mazepus@fgga.leidenuniv.nl E Institute of Public Administration, Leiden University, Wijnhaven Building, Turfmarkt 99, 2511 DV Den Haag, Leiden, Netherlands

(1) Supplemental data for this article can be accessed at http://dx.doi.org/10.1080/13569775.2017.1306762

(c) 2017 The Author(s). Published by Informa UK Limited, trading as Taylor \& Francis Group

This is an Open Access article distributed under the terms of the Creative Commons Attribution-NonCommercial-NoDerivatives License (http://creativecommons.org/licenses/by-nc-nd/4.0/), which permits non-commercial re-use, distribution, and reproduction in any medium, provided the original work is properly cited, and is not altered, transformed, or built upon in any way. 
Soest \& Grauvogel, 2015). Beyond performance, political elites justify their rule with ideology, history and national identity, charisma, religion, as well as democratic procedures. This article is concerned with two questions that are not explicitly addressed by this body of literature: (1) What do citizens expect from political authorities to grant them legitimacy? (2) Do ideas about legitimacy differ in democracies and hybrid regimes?

Building on the above mentioned studies of legitimacy claims in non-democracies, this article focuses on the 'demand side of legitimacy' and contributes specifically to the debate on legitimacy belief (see Dukalskis and Gerschewski, this issue). It does so by comparing the ideas of citizens about what constitutes a legitimate political authority in different European regimes. More precisely, this article compares the criteria set by students for political authorities in two old democracies (the Netherlands and France), a post-communist democracy (Poland), and two post-communist hybrid regimes (Ukraine and Russia). Hybrid regimes are understood as regimes that 'combine some democratic and some autocratic elements' (Hale, 2011b, p. 34) and vary from unconsolidated democracies to unconsolidated autocracies (Way, 2005). The selection of cases was driven by reasons that were both theoretical (regime differences between selected countries) and practical (access, cost, and language).

If one assumes that hybrid regimes use different strategies than democratic (and classic authoritarian) regimes to obtain legitimacy, one may also assume that citizens socialized in different political systems use different criteria to evaluate political authorities' legitimacy. As a consequence, citizens should be convinced by different arguments and characteristics of political authorities when voluntarily delegating power to them. If this is not the case, this would mean that either the legitimacy claims used by the authorities do not resonate with the citizens, that the criteria for legitimacy do not differ much across regime types, or that these strategies achieve goals different than legitimacy (e.g. preserve the power of incumbents, see Gerschewski, 2013; Kailitz, 2013).

Using data collected in a survey of students in the Netherlands, France, Poland, Ukraine, and Russia, this article shows that contrary to the expectations, there were no great differences between the ideas of citizens socialized in different regimes. Highly educated youth almost uniformly considered free and fair elections as the most important characteristic of legitimate political authorities (with the exception of Poland, where trust was named most frequently). Moreover, the similarities and differences in the expectations of respondents did not align with the regime types. Overall, the results suggest that the legitimacy beliefs of respondents from democratic and non-democratic regimes are shaped by similar expectations about how political authorities should acquire the right to rule and how they ought to behave once in office. In other words, contrary to the widespread view that people from different regimes have different conceptions of legitimacy and democracy, students socialized in different regimes seem to have very similar ideas about what makes political authorities legitimate.

Further comparative research into the expectations of citizens can help to identify similarities and differences in ideas about legitimacy across social groups. It can also contribute to the understanding of how these ideas might be shaped. This article is a step forward towards establishing the link between legitimacy claims and legitimacy beliefs in the study of legitimacy (i.e. supply and demand cycles of legitimation, see Von Haldenwang, this issue). It shows that exploring ideas about what makes authorities legitimate in the eyes of citizens can help to assess the effectiveness of the legitimation strategies of 
political authorities across regimes. Moreover, it can also help to see whether authorities respond to the ideas of citizens in their legitimation strategies.

\section{Micro-Perspectives on legitimacy: legitimacy beliefs and expectations}

Political legitimacy is the right to rule granted by citizens to political authorities or political regimes 'grounded in common good or shared moral evaluations' (Gilley, 2009, p. 5). In Easton's (1965, p. 278) words, it is 'a strong inner conviction of the moral validity of the authorities or regime'. Legitimacy claims are attempts by the authorities to convince citizens about their right to rule (see also Von Haldenwang; Grauvogel \& Von Soest, 2017). Authorities can formulate these claims drawing on different sources of legitimacy (Weber, 1947, 1978; see also Bensman, 1979). Citizens in turn, can either accept legitimation claims or reject them depending on the congruence of the claims with their expectations (legitimation demands). These expectations of citizens are the main focus of this study. The expectations and opinions of citizens are the object of studies of legitimacy from the microperspective - 'the perspective from grassroots' (Weatherford, 1992, pp. 150-151).

In studies from the micro perspective legitimacy is assessed on the basis of citizens' evaluations and the focus is on whether the institutions and authorities are perceived as rightful and fulfilling their purposes by citizens. Studies into the micro-perspective are interested in a subjective assessment of the legitimacy of political regimes. One type of studies is concerned with establishing the degree of legitimacy of political regimes by using aggregated results of public opinion surveys of citizens and regime performance indicators (e.g. Gilley, 2009). Other studies are interested in what factors influence individual level assessments of political authorities (e.g. Tyler, 2001, 2003; Tyler \& Caine, 1981; Van der Toorn, Tyler, \& Jost, 2011).The latter body of literature focuses particularly on identifying antecedents of perceived legitimacy and causal mechanisms behind granting it.

This article takes the micro perspective and zooms in on the factors that influence legitimacy according to the citizens. It provides information about what expectations young educated citizens have when they grant legitimacy to authorities in their country. It does not concern the opinion they have about the current authorities and it does not evaluate the general level of legitimacy in the country from either from the micro- or from the macro- perspective (Weatherford, 1992, p. 150).

\section{Objects of legitimacy}

The discussion of objects of legitimacy is linked to Easton's distinction between specific and diffuse support. The starting point for this discussion is the observation that citizens evaluate different objects of the political realm, namely the political system and institutions that comprise it and incumbents holding power. In Easton's understanding, the evaluation of these objects can translate into diffuse and specific support respectively, where diffuse support can be granted to political regimes and specific support to particular outputs produced by the office holders such as 'decisions, policies, actions, utterances or the general style of these authorities' (Easton, 1975, pp. 437-438).

Easton defined diffuse support as 'a reservoir of support - frequently described as patriotism, love of country, loyalty, and the like' (Easton, 1965, p. 125) and as a preference for certain institutional arrangement or 'attachment to political objects for their own sake' (Easton, 1975, p. 445). Although legitimacy is linked to diffuse support and sometimes 
the two are conflated (Fraser, 1974, p. 121), Easton (1965, p. 278) wrote about legitimacy not as an equivalent to but as one of the major sources of diffuse support:

The inculcation of a sense of legitimacy is probably the single most effective device for regulating the flow of diffuse support in favour both of the authorities and of the regime. A member may be willing to obey the authorities and confirm to the requirements of the requirements of the regime for many different reasons. But the most stable support will derive from the conviction on the part of the member that it is right and proper for him to accept and obey the authorities and to abide by the requirements of the regimes.

Moreover, legitimacy is not only 'a quality that is ascribed to the norms and structures of a regime' but it can be assigned to authorities too (and other political objects like policies and laws; in Easton, 1965, pp. 286-287; Gilley, 2006, p. 501; Rothschild, 1977, p. 494).

In this study, political authorities in general are the object of legitimacy, not necessarily the authorities that are currently holding offices. The legitimacy of political authorities is influenced by default by the ideas about what constitutes a legitimate political system and by the way in which the authorities behave. In other words, political authorities need to come to power on the basis of valid procedures for acquiring power and they need to rule in accordance with institutional standards within the political system. Moreover, they also ought to represent the style of rule that is right and achieve outputs that benefit the common good (see Von Haldenwang, 2017) in the eyes of citizens.

In this way, both specific and diffuse support is relevant for the legitimacy of political authorities. The two are also linked because the legitimacy of particular authorities incumbents - can affect the legitimacy of the whole system (Easton, 1957, p. 393, see also Table in 1965, p. 287). This can happen in any political system, but seems to be even more pronounced in non-democratic (personalized) systems, where the leadership of the country is often associated with the system itself and embodies and shapes the institutional arrangement. In addition to the general doubt about citizens' capacity to separate their preference for a regime (or political system) from particular outputs that the regime in place delivers and particular inputs it offers (Mishler \& Rose, 1996, p. 556), the distinction between the authorities and the regimes in the case of authoritarian and hybrid regimes becomes much more blurred.

\section{Dimensions of legitimacy: input, throughput, and output}

Political scientists agree that legitimacy is a multidimensional concept. There is, however, no consensus about how many dimensions it has (Alagappa, 1995, pp. 11-30; Beetham, 1991; Booth \& Seligson, 2009; Easton, 1975; Friedrich, 1963, p. 234). In this study, a distinction between input, output, and throughput will be used (Scharpf, 1998, 2003; Schmidt, 2013). It has its roots in Easton's political system analysis (1957, p. 384), which identified input (demands and support), processes within a political system, and outputs (policy decisions). Input legitimacy is concerned with the conditions that a political system provides to link authorities' actions and the 'authentic preferences of citizens' (Scharpf, 1997, p. 19). It entails mechanisms of transferring the preferences and demands of citizens to the authorities and the ways in which authorities can come to power. Output legitimacy deals with the effectiveness of the authorities in achieving common goals and solving common problems (Scharpf, 2003). Throughput legitimacy is concerned with the quality of the governance process (Schmidt, 2013 , p. 2). In other words output is about governing for the people, input is about governing 
by the people (usually referring to representation through a vote in elections), and throughput is about governing with the people (Schmidt, 2013, p. 3).

This article uses the input, throughput, and output distinction to group the criteria on the basis of which individuals attribute legitimacy to authorities. In addition, it explores how citizens prioritize these criteria of evaluation. It weighs the importance of input, output, and throughput on the basis of individual level data. More specifically, it explores the ideas of citizens about what the best institutional arrangements should be (e.g. democratic or not), what characteristics legitimate authorities should have, what are the duties of institutions and authorities according to citizens, and what procedures they ought to use.

\section{Legitimacy, regime types, and political socialization}

Political socialization is believed to shape the scope of political orientations that a young person could acquire within a given society (Easton \& Dennis, 1980, p. 7). Knowledge about political institutions and their designated authority and duties, about the way citizens and the state institutions interact, and about the formal and informal procedures guiding the behaviour of political authorities and citizens is passed on by teachers and parents, and is shaped by early experiences of associational and political life (e.g. Galston, 2001; McFarland \& Thomas, 2006). However, it is not clear to what extent the ideas about legitimacy - how a political system ought to function (i.e. ideas about an ideal political system) - differ across regimes.

Apart from the possibility that the legitimation strategies mentioned above are in line with citizens' preferences, a couple of expectation can be drawn from literature on postcommunist states. One of them is the salience of social justice. Kluegel and Mason (2004, p. 817) found a strong preference for egalitarianism among citizens in post-communist countries as a legacy of the previous political system. The citizens in these countries seem to be very sensitive to fair economic distribution. Moreover, although far from conclusive, there is some evidence that Russians might emphasize the delivery of material welfare as an important aspect of democracy (Hale, 2011a, p. 1361). However, the same study also found that most Russians associate democracy with freedoms and rights and the rule of law (see also Dalton, Sin, \& Jou, 2007, p. 147).

In the case of Russia, the common narratives used by political elites are those of stability and order as the values guiding how the country is governed. Other narratives make references to the exceptionalism of Russians and their national values. These narratives find support from citizens as reflected by public opinion surveys (see Carnaghan, 2010, p. 155), but the implications of this for the conception of legitimacy (and democracy) are not clear.

If there is a link between the conception of legitimacy held by the citizens in a given political regimes and understanding of democracy or legitimation claims used by the elites, the current study contributes to detecting them. These links should be possible to detect especially if there are substantial and long-lasting differences in the expectations that citizens have from authorities in post-communist vs. old democratic regimes.

\section{Methodology}

\section{Case selection}

To compare hybrid regimes with democracies, contrasting cases were selected. On one end two post-communist (and post-Soviet) hybrid regimes, namely Russia and Ukraine, 
were included. On the other end two old democracies - the Netherlands and France were selected. In between these contrasting cases, a new post-communist democracy - Poland was selected. Including Poland in the dataset allows for controlling for similarities between countries that share the communist past and similarities between countries that are currently considered democracies. Following from this, apart from the differences and similarities between the contrasting countries, this study is interested also in the differences and similarities between the 'relatively similar' cases (Dogan \& Pelassy, 1990, p. 132), namely between old democracies, between post-communist countries, and between hybrid regimes.

Russia and Ukraine since the 1990s have both been categorized as hybrid regimes unconsolidated democracies or unconsolidated autocracies (Way, 2005) - and many parallels were drawn between Ukraine's transition from communism under Kravchuk (19911994) and Kuchma (1994-2004) and Russia's under Yeltsin (1991-1999) and Putin's early regime (from 1999). From the moment Putin started to introduce reforms that increased his powers, curbed competition, and led to the marginalization of democratic opposition, Russia's and Ukraine's paths started to diverge more visibly (Kuzio, 2006). While Putin established the party of power - United Russia - which dominated the legislative institutions (White \& Kryshtanovskaya, 2011, p. 558; Wilson, 2009), in Ukraine this has never happened and each election reflected strong competition between two blocks that had their support bases in different regions: national-democrats oriented more towards the EU were supported by the Western and Central regions and the pro-Russian Communists/socialists were supported by the industrial regions in the East and South. Two waves of protests and an escalation of political conflict were marked in Ukraine by the Orange Revolution in 2004/2005 (Kubicek, 2009, p. 327) and the events on the Maidan in the winter of 2013/2014 (Ryabchuk, 2014).

In this dynamic situation in both countries, the categorization of the regime and the regime scores change depending on the exact timing of data collection as well as the criteria of assessment (Freedom House, 2001, 2015; Marshall \& Jaggers, 2013; The Economist Intelligence Unit, 2015; The Bertelsmann Stiftung's Transformation Index 2016). ${ }^{1}$ These rankings indicate that in general Russia and Ukraine are considered as hybrid regimes that combine electoral mechanisms and other democratic institutions with authoritarian practices. Ukraine, however, throughout the 2000s moved in the direction of democracy (albeit not without setbacks), whereas Russia has been moving towards full authoritarianism.

Next to these two post-communist - and also post-Soviet - hybrid regimes, another post-communist case was included, Poland. Poland embarked on a transition to democracy in 1989, has been a member of the European Union since 2004, and is considered one of the examples of successful democratization (The Bertelsmann Stiftung's Transformation Index 2016). Most of the above mentioned regime rankings evaluate the Polish political regime as fully democratic or as a consolidating democracy. Including it in the analysis allows a comparison of a more successful case of post-communist transition to democracy with the less successful cases of Russia and Ukraine.

As examples of old democracies, the Netherlands and France were chosen. The Netherlands is consistently placed among the most democratic countries in the world. France's regime record is similar to the Netherlands. In general, France is a slightly lower ranked democracy than the Netherlands (Marshall \& Jaggers, 2013; The 
Bertelsmann Stiftung's Transformation Index 2016), but the V-Dem project ranks the level of polyarchy in France higher than in the Netherlands in 2015 (Coppedge, Gerring, Lindberg, Skaaning, \& Teorell, 2016). While the Netherlands is a constitutional (parliamentary) monarchy, France is a semi-presidential republic. Choosing these two continental old democracies with different political systems, makes it possible to check whether there are common legitimacy ideas and perceived legitimacy patterns that come with the fact of being an old democracy or whether there are differences between European democracies too.

The particular countries were selected for theoretical reasons (outlined above; regime type and communist past) and practical reasons (access, cost, and language).

\section{Sample}

Because this study aims to compare conceptions of legitimacy among individuals socialized in different regimes, the group of citizens that were selected for the investigation is the same in each country, namely student samples between the age of 16 and 25 . In each country samples of students were collected, because they are a comparable social category in the cross-cultural context: they come from similar backgrounds, have a similar social position (at least relative to other groups within their respective societies), use the internet as a source of information more often than other groups, and - most importantly - because of their similar age, they were equally recently socialized into their respective political communities. In this way many variables are kept constant and this allowed an assessment of the differences in the evaluation criteria used to judge political authorities in the different political contexts in which the respondents grew up. Students are a homogenous population, so they constitute a suitable population for a comparative study.

Student samples can be used for researching political attitudes for several reasons. First, students are potential voters and typically participate in political and associational life. Compared to other social categories, they are more likely to become future political leaders (Mickiewicz, 2014). Because of the relatively high political engagement of students, they were likely to be relatively familiar with political concepts they were asked questions about (see Mintz, Redd, \& Vedlitz, 2006, p. 769). Second, students were the most accessible and the least costly group to sample, which allowed for relatively large samples to be collected from five countries.

Of course, sampling from a student population has limitations. The main issue is the limited possibility to generalize from students to individuals of other social categories. However, there are studies from the USA that suggest that the views of students and the general population overlap to a large extent. That is, for many variables of interest to political scientists, the variation in views among students reflects the variation in views among the general public (Druckman \& Kam, 2011, pp. 51-52). Furthermore, generalization is not the main purpose of this study. The main purpose is to do a comparative study of the influence of regime socialization with internal validity. Homogenous student samples are suitable for this. Students have been and are members of state institutions that are designed to influence their knowledge, values, and ways of thinking. If socialization into a particular political culture influences how citizens evaluate what is legitimate, then we would be especially likely to observe such differences among students. Using a student sample allows to test the political socialization theory with an emphasis on 
internal validity. If differences are found among students, further research could sample individuals from different social categories to assess the generalizability of such effects.

More than 320 respondents in each country were recruited. Data were collected in 2012 (the Netherlands), 2013 (Poland, Ukraine, Russia), and 2014 (France). I excluded respondents who were younger than 16 or older than 25 , were not citizens of the country in which the survey was conducted, or did not respond attentively. This resulted in a Dutch sample with $N=379$ out of which 292 provided at least one answer to the open question analysed here (110 females, 8 sex unknown; age $M=19.2, S D=1.6$ ), a French sample with $N=323$ out of which 196 provided an answer (114 females, 4 sex unknown, age $M=18.6, S D=1.1$ ), a Polish sample with $N=437$ out of which 269 provided an answer (156 females, 9 sex unknown, age $M=21.3, S D=1.7$ ), a Ukrainian sample with $N=429$ of which 270 provided an answer (181 females, age $M=20.1, \mathrm{SD}=2.3$ ), and a Russian sample with $N=929$ of which 413 provided an answer (191 females, 4 sex unknown, age $M=20.2, S D=2.1$ ).

\section{Survey}

The data for this study was collected as a part of a larger survey. The survey was administered as a pen-and-paper task in the Netherlands, Poland, France, and partially in Russia. Additional data in Russia was collected online and the Ukrainian sample was collected fully online.

The data collection in the Netherlands took place at the University of Leiden in September and October 2014. The French sample was collected at the University of Lyon in November and December 2014. The data collection in Poland took place at universities and higher education institutions in Poznan and Krakow in May, June, and December 2014. The data collection in Ukraine was conducted using Qualtrics online survey software. Participants of the survey were recruited from universities in Kyiv and Mykolaiv and completed the online survey between June and November 2014. The data collection in Russia was conducted using two methods. The first batch of data was collected in May and June 2014 in a survey administered as a pen-and-paper task. The second batch of data was collected in June and September-December 2014 using Qualtrics online survey software. ${ }^{2}$ For the pen-and-paper task, participants were recruited mainly from the Higher School of Economics in Moscow and 303 responses were collected. To recruit additional participants, an online link to the survey was circulated on social networks for students by a research assistant based in Moscow. Participants of the online survey included in the analysis came from over 300 different universities and higher education institutions located in many regions of Russia. ${ }^{3}$ In each country the study was conducted in the native language of respondents. The English text was the basis for all translations, although the translators of the Ukrainian and Russian version consulted also the wordings in Russian and Polish, respectively. All translations were completed or proof-read by at least one native speaker. Small pilot studies in the Netherlands (with international students) and in Russia checked if the phrasing is understandable to the respondents.

\section{Open question and development of the coding scheme}

The word legitimacy is used in many academic and public debates. It appears frequently in the press and other mass media. However, many scholars believe that using the word itself 
to ask a question about legitimacy to citizens is too confusing, too difficult, or too abstract. Legitimacy is a latent concept and scholars often debate and contest its meaning and devise proxies for empirical measurement. It is unclear to what extent the understanding of scholars coincides with the meaning assigned to the word by a broader educated audience, especially in a cross-cultural context. While the proxies used so far might give an indication of the trends in legitimacy, people's understanding of it could bring new insights into the weight of different supposed components of legitimacy. In other words, before we ask people their opinion about factors contributing to legitimacy, we need to establish which factors they think influence legitimacy. Following this subjective approach, in this study, participants had the opportunity to answer an open question: 'In your opinion, what are the characteristics of legitimate authorities? Please list up to five characteristics in order of importance $(1=\text { most important })^{\prime}$.

This question intentionally does not guide respondents to focus either on the legitimacy of institutions or on the individuals who take positions within them. First of all, this allows for the exploration of the full scope of associations that citizens have with legitimacy. Second, it does not steer the attention of respondents to particular institutions that could be more important in one regime type, but less in another. Finally, it is not assumed that respondents draw a clear line between institutions (such as elections or parliament) and the characteristics of people who represent them. As explained above, particular individuals draw their authority from institutions and affect institutions at the same time.

To be able to analyse these answers, a coding scheme was developed with the help of two other coders. In the first round of coding two coders each received a random sample of $10 \%$ of the participants from one country who gave at least one answer to the question. Coder 2 received a 10\% random sample of participants from the Netherlands and Coder 3 received a $10 \%$ random sample of participants from Poland. The author coded both random samples (Coder 1). Coders 2 and 3 received instructions in which they were asked to code the answers in two ways.

First, the coders were asked to use the coding strategy sometimes referred to as 'representational coding': using codes that represent what is 'out there' as closely as possible (Sapsford \& Jupp, 2006, pp. 170-171). The idea behind this coding is to represent as closely as possible the answers of respondents while grouping these answers into categories (hence, reducing the number of answers). The difficulty is to find the right balance between the number of categories (codes) and the number of phenomena and ideas expressed by respondents.

Second, the coders were asked to conduct a hypothesis-guided coding. In this type of coding a theoretical distinction guides the process of assigning specific codes (Sapsford \& Jupp, 2006, pp. 170-171). The coders were asked to interpret the answers from the point of view of a legitimacy theory and categorize them according to the input, throughput and output dimensions of legitimacy discussed above. The coders, who are familiar with the political legitimacy literature, received a brief description of each of the three categories (dimensions of legitimacy).

There were three rounds of coding involving three coders and two rounds of discussion involving two coders that resulted in reasonably high inter-coder reliability. In the final round Coder 1 and Coder 2 achieved complete agreement for about $77.4 \%$ of codes. Coder 1 and Coder 3 completely agreed for about $81.7 \%$ of codes. There were several groups of words and phrases the coders did not always agree about. These codes and 
phrases carry similar meanings, but are distinct. A couple of examples are words ultimately coded as justice, such as 'justice' or 'righteousness' that were distinguished from words coded as legality/legal validity such as 'constitutionality', 'being formed on the basis of law', 'lawfulness', 'legality', 'following the laws', 'not breaking the laws'. In addition, a separate code was created for phrases and words referring specifically to the system of checks and balances, such as 'the need for separation of powers', 'presence of different institutions - including courts', 'accountability of the institutions in front of each other and in front of the people', and 'limitations on the political authorities' powers'. The final list of codes used to categorize the answers of respondents is presented in the online Appendix 1. The trade-off between keeping such a large number of codes and inter-coder reliability is lower inter-coder reliability against more meaningful categories of codes.

The hypothesis-guided code list is presented in the online Appendix 2. The dimensions of input, throughput, and output were used to organize the representational codes. Input was specified as the basis on which authorities are representing the people - it refers to the reasons people give to designate others to act on their behalf. This included the ways in which the interests of the citizens can reach (potential) authorities, who in turn can become their representatives. Any input of ideas or interests of citizens in the political process was included in the input dimension. ${ }^{4}$ Moreover, the expressions of consent such as support and trust (these two are often highly correlated), were included in the dimension of input, following Easton (1957, p. 384). Throughput referred to the process of the use of power and personal characteristics of authorities that influence how the authorities govern. Output was defined as including all (expected) results of governing - in other words, the outcomes of the use of power (Bovens, 2005). The representational codes were assigned to the most suitable dimensions of legitimacy. This means that there were cases in which a code could have been assigned to more than one dimension of legitimacy. For example, the coders thought that 'justice' could be assigned to either throughput or output. In cases like this, after consultation between the coders, this kind of code was assigned to the dimension most coders agreed on. Online Appendix 2 lists the representational codes that were assigned to each of legitimacy dimensions (hypothesis-guided codes).

\section{Results}

Respondents provided 5148 answers (see Appendix 3 available online for the frequencies of answers in each country). As mentioned above, the answers were organized and coded in two ways: with the representational codes and with the hypothesis-guided codes.

\section{Comparison of the representational codes: all answers}

Table 1 presents rank orders of coded answers from the most popular to the least popular. Table 2 shows the differences between the top ten most frequent answers in each country expressed as percentages of the total number of answers.

Answers related to elections were the most frequent (across all the answers) in France only. It was also the only country in which the most popular answer - elections - clearly dominated over the next frequently given answer. Elections were named $15.8 \%$ of the time, whereas the second most popular answer - justice - constituted $8.1 \%$ of the 
answers (a difference of 7.7\%). In all the other countries the difference between the top answer and the second most frequent answer was much smaller (between $0.4 \%$ in Russia and $3.6 \%$ in Poland), making elections clearly the most emphasized answer in France. Although less popular, elections was the second most frequently given answer by respondents from Ukraine (10.9\% of answers), Russia (11.7\%) and the Netherlands (8.3\%). Poland was the only country in which elections were not among the top two most popular answers: in Poland elections constituted 5.9\% of all the answers and were in the seventh position of most frequent answers.

Transparency was the most frequent code in Ukraine (11.1\%) and in the Netherlands (9.2\%). The distribution of answers categorized as transparency in these two cases differed though. In Ukraine, $41.6 \%$ of answers coded as transparency directly named the absence of corruption as the most important characteristic of legitimate authorities. In the Netherlands, only $6.3 \%$ of answers were directly related to corruption. Most respondents used words such as openness, transparency, and clarity. In Russia, transparency was also ranked relatively high. It was the fourth most frequent answer (6.5\% of all answers). Similar to Ukraine, almost $40 \%$ of the answers were emphasizing that legitimate political authorities should not be corrupt.

In Poland, the most frequent answer was trust/support (13.1\%). In Russia, $7.2 \%$ of respondents said that a characteristic of legitimate authority is that people trust or

Table 1. Rank orders of codes (frequencies of all answers).

\begin{tabular}{|c|c|c|c|c|c|}
\hline Code & NL & FR & $\mathrm{PL}$ & UA & RU \\
\hline Transparency & 1 & 14 & 13 & 1 & 4 \\
\hline Elections & 2 & 1 & 7 & 2 & 2 \\
\hline Legal validity / legality & 3 & 11 & 3 & 4 & 1 \\
\hline Checks \& balances & 4 & 5 & 18 & 12 & 8 \\
\hline Honesty / fairness & 5 & 24 & 11 & 6 & 12 \\
\hline Impartiality & 6 & 10 & 13 & 15 & 12 \\
\hline (De facto) authority & 7 & 7 & 5 & 9 & 10 \\
\hline Representation / pluralism & 8 & 8 & 15 & 14 & 17 \\
\hline Integrity & 9 & 4 & 4 & 3 & 7 \\
\hline Citizen participation / consultation & 10 & 3 & 16 & 11 & 14 \\
\hline Reliability & 10 & 16 & 10 & 15 & 22 \\
\hline Justice & 12 & 2 & 2 & 8 & 5 \\
\hline Democracy & 13 & 13 & 19 & 17 & 21 \\
\hline Acting for the common good / for citizens & 14 & 5 & 6 & 5 & 7 \\
\hline Expertise & 14 & 12 & 12 & 10 & 18 \\
\hline Other & 16 & 16 & 8 & 21 & 9 \\
\hline Protection of individual rights / freedoms & 17 & 18 & 16 & 19 & 16 \\
\hline Trust / Support & 18 & 23 & 1 & 7 & 3 \\
\hline Equality & 19 & 9 & 22 & 25 & 20 \\
\hline Security / order / stability & 20 & 20 & 19 & 23 & 25 \\
\hline Acceptance / approval & 21 & 14 & 8 & 13 & 11 \\
\hline Welfare / economic prosperity & 22 & 21 & 27 & 19 & 15 \\
\hline Traditional / religious & 23 & 29 & 25 & 28 & 28 \\
\hline Leadership / charisma & 24 & 22 & 25 & 28 & 24 \\
\hline National interest / sovereignty & 25 & 24 & 23 & 21 & 19 \\
\hline Efficiency & 26 & 19 & 21 & 28 & 30 \\
\hline Ideological & 26 & 28 & 24 & 27 & 28 \\
\hline International recognition & 26 & 30 & 30 & 23 & 23 \\
\hline Foreign policy & 29 & 30 & 27 & 28 & 26 \\
\hline Patriotism / nationalism & 30 & 27 & 29 & 18 & 26 \\
\hline National unity & 31 & 24 & 31 & 25 & 30 \\
\hline
\end{tabular}

Note: Double (or triple) ranks (e.g. within a country two or three codes with the same rank number) mean that those codes were mentioned the same number of times in a sample. 
Table 2. Ten most frequent answers in the Netherlands, France, Poland, Ukraine, and Russia (answers from all positions).

\begin{tabular}{|c|c|c|c|c|c|c|c|c|c|c|}
\hline & The Netherlands $(N=1048)$ & $\%$ & France $(N=701)$ & $\%$ & Poland $(N=1046)$ & $\%$ & Ukraine $(N=1019)$ & $\%$ & Russia $(N=1333)$ & $\%$ \\
\hline 1 & Transparency & 9.15 & Elections & 15.83 & Trust/Support & 12.62 & Transparency & 11.09 & Legal validity/legality & 12.09 \\
\hline 2 & Elections & 8.30 & Justice & 8.13 & Justice & 9.46 & Elections & 10.89 & Elections & 11.71 \\
\hline 3 & Legal validity/legality & 7.25 & $\begin{array}{l}\text { Citizen participation/ } \\
\text { consultation }\end{array}$ & 6.56 & Legal validity/legality & 8.41 & Integrity & 10.79 & Trust/Support & 7.21 \\
\hline 4 & Checks \& balances & 7.06 & Integrity & 6.42 & Integrity & 7.46 & Legal validity/legality & 8.15 & Transparency & 6.46 \\
\hline 5 & Honesty/fairness & 6.97 & Acting for the common good & 5.71 & (De facto) authority & 7.36 & $\begin{array}{l}\text { Acting for the common } \\
\text { good }\end{array}$ & 7.56 & Justice & 5.71 \\
\hline 6 & Impartiality & 5.82 & Checks \& balances & 5.71 & $\begin{array}{l}\text { Acting for the common } \\
\text { good }\end{array}$ & 7.07 & Honesty/fairness & 6.48 & $\begin{array}{l}\text { Acting for the common } \\
\text { good }\end{array}$ & 5.48 \\
\hline 7 & (De facto) authority & 5.73 & (De facto) authority & 5.42 & Elections & 5.93 & Trust/Support & 6.08 & Integrity & 4.95 \\
\hline 8 & Representation/pluralism & 5.06 & Representation/pluralism & 5.28 & Acceptance/approval & 4.11 & Justice & 5.10 & Checks \& balances & 4.80 \\
\hline 9 & Integrity & 4.96 & Equality & 4.42 & Reliability & 3.82 & (De facto) authority & 4.91 & (De facto) authority & 4.13 \\
\hline 10 & $\begin{array}{l}\text { Citizen participation/ } \\
\text { consultation }\end{array}$ & 4.58 & Impartiality & 3.85 & Honesty/fairness & 3.35 & Expertise & 4.42 & Acceptance/approval & 3.83 \\
\hline
\end{tabular}


support it, while in Ukraine, trust/support constituted $6.1 \%$ of the answers. In France and the Netherlands, trust/support was not among the top ten answers provided by respondents.

Legal validity/legality was among the most common codes in four out of five countries. In Russia, it constituted $12.1 \%$ of the answers and it was the answer that was mentioned most often (elections were only $0.4 \%$ less popular). Legal validity/legality was the third most frequent answer in Poland (8.4\%) and the Netherlands (7.3) and it was the fourth category in Ukraine (8.2\%). Only in France was legal validity/legality not among the top ten most frequent answers.

Although legal validity/legality was not a common expression used to describe a legitimate authority in France, the second most frequently used word was justice, which has a meaning related to the legal validity/legality category. Justice was the second most frequent answer in France (8.1\%) as well as in Poland (8.4\%). It was the fifth most frequent answer in Russia (5.7\%) and eighth in Ukraine (5.1\%).

The word justice and related phrases were not used often by Dutch respondents. However, other codes touching upon similar themes were assigned frequently to their answers, such as the above mentioned legal validity/legality and the words and phrases coded as impartiality (5.8\%), which are related to the theme of justice.

Integrity was among the top most frequent answers in all five countries. It was the third most frequent category in Ukraine (10.8\%), fourth in Poland and France $(7.5 \%$ and $6.4 \%$ respectively), seventh in Russia (5\%) and ninth in the Netherlands (5\%). Another answer that appeared in every sample was (de facto) authority (Poland $7.4 \%$, the Netherlands 5.7\%, France 5.4\%, Ukraine $4.9 \%$ and Russia $4.1 \%$ ).

The category 'acting for the common good/for citizens' was emphasized by respondents in four countries: in Ukraine (7.6\%), Poland (7.1\%), France (5.7\%), and Russia (5.5\%). It was not among the top ten most frequent answers in the Netherlands only.

Instead, in the Netherlands, there was more emphasis on representation and pluralism (5.1\%) and citizen participation and consultation (4.6\%). These answers were also common in France, where citizen participation/consultation was the third most frequent answer $(6.6 \%)$ and representation/pluralism was the eighth most frequent answer (5.3\%). In all three post-communist countries representation/pluralism was named less often (Poland $2.6 \%$, Ukraine $2.4 \%$, and Russia $2.4 \%$ ). Also citizen participation/consultation was not among the most popular codes in these three countries (Poland 2.4\%, Ukraine 3.5\%, and Russia 3.1\%).

Table 3 shows the differences between the most common first answers (listed in first place; hence the most important characteristic of legitimate authorities). These differences are tested in the next section.

\section{Comparison of the hypothesis-guided codes}

Hypothesis-guided codes were assigned to respondents' answers following the theoretical distinction between the input, throughput, and output dimensions of legitimacy. To test whether the responses in different countries varied across this distinction, answers from the top position that belonged to each dimension were summarized according to earlier defined terms (see online Appendix 2). The total frequencies are shown in Table 4. 
Table 3. Ten most frequent first answers in the Netherlands, France, Poland, Ukraine, and Russia (the most important characteristic of legitimate authorities).

\begin{tabular}{|c|c|c|c|c|c|c|c|c|c|c|}
\hline & The Netherlands $(N=292)$ & $\%$ & France $(N=189)$ & $\%$ & Poland $(N=269)$ & $\%$ & Ukraine $(N=271)$ & $\%$ & Russia $(N=409)$ & $\%$ \\
\hline 1 & Elections & 20.14 & Elections & 46.03 & Trust/Support & 23.42 & Elections & 26.20 & Elections & 24.21 \\
\hline 2 & Honesty/fairness & 9.22 & Justice & 8.99 & Justice & 15.24 & Honesty/fairness & 10.70 & Legal validity/legality & 15.16 \\
\hline 3 & Transparency & 7.85 & Integrity & 5.29 & Elections & 13.75 & Trust/Support & 9.96 & Trust/Support & 12.71 \\
\hline 4 & Legal validity/legality & 7.85 & Representation/ pluralism & 5.29 & Acceptance/approval & 6.69 & Transparency & 7.75 & Acceptance/approval & 6.60 \\
\hline 5 & Reliability & 7.85 & Acceptance/Approval & 5.29 & Legal validity/legality & 6.32 & Legal validity/legality & 7.38 & Justice & 5.87 \\
\hline 6 & Impartiality & 6.83 & Democracy & 4.23 & (De facto) authority & 5.95 & Justice & 7.01 & $\begin{array}{l}\text { Acting for the common } \\
\text { good }\end{array}$ & 4.89 \\
\hline 7 & (De facto) authority & 6.14 & Acting for the common good & 3.70 & $\begin{array}{l}\text { Acting for the common } \\
\text { good }\end{array}$ & 4.09 & $\begin{array}{l}\text { Acting for the common } \\
\text { good }\end{array}$ & 5.90 & Honesty/fairness & 4.40 \\
\hline 8 & Justice & 5.46 & Equality & 3.17 & Honesty/fairness & 2.97 & Acceptance/approval & 4.06 & Transparency & 3.67 \\
\hline 9 & Democracy & 5.46 & Legal validity/ legality & 3.17 & Reliability & 2.97 & (De facto) authority & 3.32 & (De facto) authority & 3.18 \\
\hline 10 & Checks \& balances & 4.78 & $\begin{array}{l}\text { Citizen participation/ } \\
\text { consultation }\end{array}$ & 2.12 & Impartiality & 2.23 & Integrity & 2.95 & Integrity & 2.93 \\
\hline
\end{tabular}


To test whether the frequency distributions of the top answers differed across countries, frequencies were analysed with a Pearson's Chi-square test. There was a significant association between the legitimacy aspects and country, $X^{2}(8)=46.16, p<.001$. To assess which frequencies contributed to the association, the standardized residuals were examined (Field, 2013, pp. 726-746). Standardized residuals are an index how much the observed frequency in a cell deviates from the expected frequency for that cell based on the row and columns totals (i.e. the number of times a theme was mentioned across all countries and the total frequency for each country). Standardized residuals indicated that input was mentioned significantly less often (than expected) in the Netherlands (std. residual = $-3.04, p<.01$ ) and significantly more often in France (std. residual $=3.43, p<.001$ ), and that throughput was mentioned significantly less often in France (std. residual $=-2.68$, $p<.01$ ) and significantly more often in the Netherlands (std. residual $=3.34, p<.001$ ). No significant cell deviations were observed for output, but the frequency of output in France (7\%) was marginally lower than expected (std. residual $=-1.92, p=.055$ ).

Table 5 shows the frequencies of answers from all positions for each country organized according to the legitimacy dimensions.

The results of the cross-country comparison of frequencies of all answers align with the results of the test for the first answers. Throughput was mentioned most frequently by Dutch respondents (58.4\%) and least frequently by French participants (45.8\%). Also input results were similar: input was least frequently mentioned in the Netherlands (26.6\%) and most frequently in France (36.1\%). Some variation was observed for the frequencies of output with the highest frequency in Poland (21.1\%) and the lowest frequency in the Netherlands (15\%).

\section{Discussion: what differs on the demand side of legitimacy?}

The analysis of representational codes showed that the scope of answers given by respondents did not differ much across the five countries. General concepts that the answers referred to were very similar, but the emphasis was on different specific characteristics of political authorities.

Two main differences were detected between the old democracies and the post-communist countries. First, a greater priority was given to trust/support by respondents from post-communist countries (Poland, Ukraine, and Russia), indicating that perhaps they experience political authorities in their countries as not trustworthy and not deserving the support. Another possible explanation is that a vote in elections alone does not necessarily indicate support or trust for particular political authority. It can be a sign of

Table 4. Frequency of aspects per country (answers from top positions only).

\begin{tabular}{lccccc}
\hline & Netherlands & France & Poland & Ukraine & Russia \\
\hline Input & 103 & 121 & 130 & 125 & 195 \\
& $(35.40 \%)$ & $(65.05 \%)$ & $(49.24 \%)$ & $(46.30 \%)$ & $(48.51 \%)$ \\
Throughput & 154 & 52 & 96 & 112 & 158 \\
& $(52.92 \%)$ & $(27.96 \%)$ & $(36.36 \%)$ & $(41.48 \%)$ & $(39.30 \%)$ \\
Output & 34 & 13 & 38 & 33 & 49 \\
& $(11.68 \%)$ & $(6.99 \%)$ & $(14.39 \%)$ & $(12.22 \%)$ & $(12.19 \%)$ \\
Total & 291 & 186 & 264 & 270 & 402 \\
& $(100 \%)$ & $(100 \%)$ & $(100 \%)$ & $(100 \%)$ & $(100 \%)$ \\
\hline
\end{tabular}


Table 5. Frequency of legitimacy aspects per country (answers from all positions).

\begin{tabular}{lcccccc}
\hline & Netherlands & France & Poland & Ukraine & Russia & Mean\% \\
\hline Input & 270 & 246 & 315 & 281 & 399 & $30.74 \%$ \\
& $(26.60 \%)$ & $(36.12 \%)$ & $(31.47 \%)$ & $(27.96 \%)$ & $(31.54 \%)$ & \\
Throughput & 593 & 312 & 475 & 546 & 621 & $51.02 \%$ \\
& $(58.42 \%)$ & $(45.81 \%)$ & $(47.45 \%)$ & $(54.33 \%)$ & $(49.09 \%)$ & $18.24 \%$ \\
Output & 152 & 123 & 211 & 178 & 245 & \\
& $(14.98 \%)$ & $(18.06 \%)$ & $(21.08 \%)$ & $(17.71 \%)$ & $(19.37 \%)$ & \\
Total & 1015 & 681 & 1001 & 1005 & 1265 & \\
& $(100 \%)$ & $(100 \%)$ & $(100 \%)$ & $(100 \%)$ & $(100 \%)$ & \\
\hline
\end{tabular}

disappointment with incumbents or no viable alternatives. Following Rose (1995, p. 550), if 'the choice offered is between more or less distrusted parties, then voters can only be 'negatively represented' by voting to turn the rascals out or keep the less unsatisfactory alternative in office'. By emphasizing trust in and support for the authorities as an important characteristic for recognizing them as legitimate, they express the need for a genuine preference for these authorities rather than voting for someone simply because they are the most acceptable option among all bad ones. Moreover, for respondents from the postcommunist countries the idea of elections as purely ritualistic and meaningless act might be more salient, because of their parents' experience with the communist involuntary mobilization (Di Palma, 1991). Therefore, beside the procedures for free and fair elections, they express the need to be able to trust and support the authorities.

Secondly, in samples from old democracies citizen participation/consultation and representation/pluralism were emphasized more than in the post-communist countries. The communist past seems to be linked to the lower level of activism (e.g. Howard, 2003) and this effect might have spilled over to the younger generations as well in these countries. In comparison with other post-communist countries, the percentage of mentions of citizen participation in Ukraine was higher. This can reflect the events that preceded the data collection the mass protests referred to as Euromaidan that were attended by many students.

French respondents stand out in their emphasis on elections and general suffrage as the most important characteristic of legitimate authorities. This might indicate prioritizing the idea of representative democracy over associational democracy. This preference for representative democracy has been discussed in the context of French democracy as a result of the belief that the state's mission is to protect the general interest rather than particularist or group interests (Saurugger, 2007).

Dutch respondents stand out as the only ones who did not mention acting for the common good as one of the most important characteristics of legitimate authorities. However, Dutch respondents emphasized 'impartiality' and 'reliability' more than respondents in other countries. In this way they focused on the characteristic of the individuals in power rather than the outcomes they should deliver. Having these characteristics though can be seen as a precondition to deliver the common good and act for the citizens' benefit.

The results showed that general idea that transparency is very important for legitimacy was shared by Dutch and Ukrainian respondents, but what needs to be done to either achieve it (in Ukraine) or sustain/improve it (in the Netherlands) differed depending on the current state of transparency. While in Ukraine and Russia 'the abuse of entrusted power for private gain' was underscored by respondents, making sure that authorities 'act visibly and understandably, and report on their activities' seems to have been more important in the Netherlands (Transparency International ${ }^{5}$ ). 
In Russia, as in all the other countries, output was not the largest category of answers. Public opinion surveys and literature on regime survival suggested that the sources of legitimacy in non-democracies might be different than in stable democracies. Previous research suggested also the importance of social justice in post-communist countries and the focus of citizens on the delivery of material welfare to citizens by the state. This implied that output (including answers such as welfare, order, stability, acting for the common good, and answers expressing the power to execute decisions) might be the most important dimension of legitimacy in these countries. This was not confirmed by the results of this study.

Instead, the characteristic of legitimate authorities named most frequently in Russia was legal validity/legality. Issues such as justice and impartiality ranked high on the list of answers too. Therefore, if order is understood not as a preference for a strong leader, but for the rule of law, then the results can be interpreted as supporting the idea that Russian citizens care about order, but so do citizens in democracies.

The results of the analysis of hypothesis-guided coding are in line with the findings based on the analysis of representational coding. It showed again that for French respondents input - elections, representation, and citizen participation - were a priority requirement to be fulfilled by legitimate authorities. Dutch respondents put more emphasis on throughput, which included such characteristics of political conduct as impartiality, transparency, and professionalism. At the same time, they put less emphasis on output - acting for the common good, welfare, security, and protection of individual rights - than respondents in other countries. Importantly, this analysis showed that the differences between the countries cannot be clearly drawn along the lines of regime type. Two old democracies differed more from each other than from post-communist countries.

\section{Conclusions}

This study explored the 'demand side of legitimacy' by focusing on the expectations that citizens have towards political authorities. It explored what citizens expect from political authorities in different political regimes to grant them legitimacy. Because political legitimacy (studied from the bottom up) is in the eye of the beholder, different agents - academics, politicians, leaders, citizens, ethnic groups, generations - can have different conceptions of legitimacy. Here the focus was on students' conceptions of legitimacy in five different countries to discover their ideas about the most important characteristics of legitimate authorities. Literature on legitimation strategies in non-democracies and ideas about political socialization suggested that we might expect different conceptions of legitimacy across different regimes types. Therefore the second goal of this study was to compare the ideas about legitimacy in two old democracies, a new (post-communist) democracy, and two post-communist hybrid regimes.

The first important conclusion from the process of coding of students' answers is that in all five countries similar concepts and themes were used to express what the characteristics of legitimate authorities are. It implies that similar ideas and words explain the concept of legitimacy regardless of the regime type within which respondents were socialized. Moreover, the least popular answers were also very similar across all cases. The issues linked to foreign policy, national identity, and patriotism were not the main criteria of legitimacy of political authorities either in Russia or in any other country. 
Throughput (fair procedures, legality, and integrity of authorities) and input (election, trust/support/and representation) were in general much more frequent answers than output (welfare, order, stability, acting for the common good, and answers expressing the power to execute decisions) in samples from all five countries. It does not imply that output is unimportant for any evaluation of political authorities or cannot be more important for respondents' behaviour (e.g. the decision which party to vote for). It rather implies that output is not as important as throughput and input for the judgments concerning the legitimacy of authorities.

Two main differences between samples from post-communist countries and old democracies were in regard to the input category. First, although input was in general important in each country, respondents in the post-communist countries emphasized trust/support more than respondents in old democracies. Second, a larger emphasis was given to citizen participation and consultation in the old democracies than in postcommunist countries. In line with the earlier studies, this can be explained by the experience of communism and the lack of willingness to engage in politics and social activism in the post-communist era.

There are two main limitations to this study. First, the causal relation between political socialization and ideas on legitimacy cannot be established here. Moreover, it cannot be established how the current ideas about legitimacy relate to the legitimation strategies of the political authorities in a particular regime or to the legacy of previous regimes. Further studies can aim to discover how the legitimation strategies are linked to the expectations, legitimation beliefs, and behaviour of citizens. Second, this study compared the ideas of only one group of citizens and cannot be generalized to other social groups. A comparison of the ideas of other social groups (e.g. pensioners, the unemployed, lower-educated citizens, state-employees) across countries could build on the current study.

To summarize, this study provided a detailed picture of ideas about what characteristics legitimate authorities should have according to students in the five countries under investigation. Contrary to the expectation, across regime types students had largely similar ideas about what legitimacy is. In both democratic and hybrid regimes respondents found it important for legitimacy that the authorities gain power as a result of free and fair election, they act in a transparent, fair, and legal way, and they show integrity and reliability. Linking these results to the papers in this special issue that study legitimacy claims in non-democratic regimes, the question that requires further investigation is whether legitimacy claims are in line with citizens' views about what makes authorities legitimate. If the claims of authorities do not align with the demand side of legitimacy, can they ever achieve legitimacy or can they only achieve instrumental acceptance?

\section{Notes}

1. As different regime rankings evaluate the level of authoritarianism and democracy in Russia and Ukraine differently, I use the term hybrid regimes to describe them (rather than closed and electoral authoritarianism used in other articles in this special issue).

2. I tested for the effect of data collection mode using the quantitative data from the survey. Very small differences in the effect sizes were found, but the patterns of correlations were the same in both samples. In general, the associations between variables were very similar in the online and pen-and-paper samples. This suggests that the mode of collection did not substantially affect the results of the survey. 
3. In the Netherlands students were prevailingly recruited from history and political science programmes; in France they were recruited, among others, from economy and management, applied studies of foreign languages, sociology, political science, law, and art history; in Poland from journalism, economy, management, public administration, American studies, national security, international relations, and social communication; in Ukraine, among others, from history, linguistics, political science, languages, journalism, law, ecology, and engineering; in Russia students were recruited from the most diverse programmes ranging from university to professional education.

4. This understanding of input is close to Beetham's 'consent' dimension of legitimacy in the modern state in its electoral and mobilizational forms (1991, pp. 150-158).

5. Https://www.transparency.org/what-is-corruption\#define

\section{Acknowledgments}

I thank Elisabeth Dieterman and Anne Heyer for their support in coding of the data. I thank Florian van Leeuwen, Antoaneta Dimitrova, Matthew Frear, two anonymous reviewers, and the editors of the journal and of the special issue for their valuable comments. For their help with data collection, I thank Agata Mazepus, Marcin Piechocki, Paweł Stachowiak, Paweł Laidler, Marcin Grabowski, Justyna Zadarko (Polish sample), Henk Kern, Femke Bakker, Niels van Willigen, Adriaan van Veldhuizen, Max Bader (Dutch sample), Tadeg Quillien, Helena Miton, Florian van Leeuwen (French sample), Olena Czemodanova, Oleksandr Pronkevych, Jaroslav Dansynenko (Ukrainian sample), Ekaterina Dergunova, Ekaterina Lytkina, Alexis Belyanin, Inna Devyatko, Mikhail Mironyuk, Svetlana Bankovskaya, Valeri Ledyaev, and Tatiana Karabchuk (Russian sample).

\section{Disclosure statement}

No potential conflict of interest was reported by the author.

\section{Notes on contributor}

Dr Honorata Mazepus works at Leiden University as a post-doctoral researcher on the EU-STRAT project funded by the European Union's Horizon 2020 research and innovation programme.

\section{References}

Alagappa, M. (1995). Political legitimacy in Southeast Asia: The quest for moral authority. Stanford, CA: Stanford University Press.

Beetham, D. (1991). The legitimation of power. Houndmills: Macmillan.

Bensman, J. (1979). Max Weber's concept of legitimacy: An evaluation. Conflict and Control: Challenge to Legitimacy of Modern Governments, 7, 17-48.

Booth, J. A., \& Seligson, M. A. (2009). The legitimacy puzzle in Latin America: Political support and democracy in eight nations. New York: Cambridge University Press.

Bovens, M. A. P. (2005). De verspreiding van de democratie. B en $M$ : tijdschrift voor beleid, politiek en maatschappi, 32(3), 119-127.

Carnaghan, E. (2010). Out of order: Russian political values in an imperfect world. University Park, PA: Penn State Press.

Coppedge, M., Gerring, J., Lindberg, S. I., Skaaning, S.-E., \& Teorell, J. (2016). Codebook v6. Varieties of democracy (V-Dem) project. Retrieved August 10, 2016, from https://www.v-dem.net/en/.

Dalton, R. J., Sin, T., \& Jou, W. (2007). Understanding democracy: Data from unlikely places. Journal of Democracy, 18(4), 142-156.

Di Palma, G. (1991). Legitimation from the top to civil society: Politico-cultural change in Eastern Europe. World Politics, 44(1), 49-80. 
Dogan, M., \& Pelassy, D. (1990). How to compare nations: Strategies in comparative politics. Chatham, $\mathrm{NJ}$ : Chatham House.

Druckman, J. N., \& Kam, C. D. (2011). Students as experimental participant. In J. N. Druckman, D. P. Green, J. H. Kuklinski, \& A. Lupia (Eds.), Cambridge handbook of experimental political science (pp. 41-57). Cambridge: Cambridge University Press.

Easton, D. (1957). An approach to the analysis of political systems. World Politics, 9(3), 383-400.

Easton, D. (1965). A systems analysis of political life. New York: Wiley.

Easton, D. (1975). A re-assessment of the concept of political support. British Journal of Political Science, 5(4), 435-457.

Easton, D., \& Dennis, J. (1980). Children in the political system: Origins of political legitimacy. Chicago \& London: University of Chicago Press.

The Economist Intelligence Unit. (2015). Democracy index 2015: Democracy in the age of anxiety. Retrieved from http://www.eiu.com/Handlers/WhitepaperHandler.ashx?fi=ElU-Democracy-Index2015. pdf\&mode=wp\&campaignid=Democracylndex2015.

Field, A. (2013). Discovering statistics using IBM SPSS statistics. Los Angeles, CA: Sage.

Fraser, J. (1974). Validating a measure of national political legitimacy. American Journal of Political Science, 18(1), 117-134.

Freedom House. (2001). Russia: Country report. Freedom in the World 2001. Retrieved July 10, 2016, from https://freedomhouse.org/report/freedom-world/2001/russia.

Freedom House. (2015). Freedom in the world. Retrieved August 21, 2015, from https://freedomhouse. org/report-types/freedom-world\#.Vdc2e5degqO.

Friedrich, C. J. (1963). Man and his government: An empirical theory of politics. New York: McGraw-Hill.

Galston, W. A. (2001). Political knowledge, political engagement, and civic education. Annual Review of Political Science, 4(1), 217-234.

Gerschewski, J. (2013). The three pillars of stability: Legitimation, repression, and co-optation in autocratic regimes. Democratization, 20(1), 13-38.

Gilley, B. (2006). The meaning and measure of state legitimacy: Results for 72 countries. European Journal of Political Research, 45(3), 499-525.

Gilley, B. (2009). The right to rule: How states win and lose legitimacy. New York: Columbia University Press.

Hale, H. E. (2011a). The Myth of mass Russian support for autocracy: The public opinion foundations of a hybrid regime. Europe-Asia Studies, 63, 1357-1375.

Hale, H. E. (2011b). Hybrid regimes. In N. J. Brown (Eds.), The dynamics of democratization: Dictatorship, development, and diffusion (pp. 23-45). JHU Press.

Holbig, H., \& Gilley, B. (2010). Reclaiming legitimacy in China. Politics \& Policy, 38(3), 395-422.

Holmes, L. (1993). The end of communist power: Anti-corruption campaigns and legitimation crisis. Cambridge: Polity Press.

Howard, M. M. (2003). The weakness of civil society in post-communist Europe. Cambridge: Cambridge University Press.

Kailitz, S. (2013). Classifying political regimes revisited: Legitimation and durability. Democratization, 20(1), 39-60.

Kluegel, J. R., \& Mason, D. S. (2004). Fairness matters: Social justice and political legitimacy in postcommunist Europe. Europe-Asia Studies, 56(6), 813-834.

Kubicek, P. (2009). Problems of post-post-communism: Ukraine after the orange revolution. Democratization, 16(2), 323-343.

Kuzio, T. (2006). Ukraine is not Russia: Comparing youth political activism. Sais Review, 26(2), 6783.

Marshall, M. G., \& Jaggers, K. (2013). Polity IV project: Political regime characteristics and transitions, 1946-2013. Retrieved from http://www.systemicpeace.org/polity/polity4.htm.

Mazepus, H., Veenendaal, W., McCarthy-Jones, A., \& Trak Vásquez, J. M. (2016). A comparative study of legitimation strategies in hybrid regimes. Policy Studies, 37(4), 350-369.

McFarland, D. A., \& Thomas, R. J. (2006). Bowling young: How youth voluntary associations influence adult political participation. American Sociological Review, 71(3), 401-425.

Mickiewicz, E. (2014). No illusions: The voices of Russia's future leaders. Oxford: Oxford University Press. 
Mintz, A., Redd, S. B., \& Vedlitz, A. (2006). Can we generalize from student experiments to the real world in political science, military affairs, and international relations? Journal of Conflict Resolution, 50(5), 757-776.

Mishler, W., \& Rose, R. (1996). Trajectories of fear and hope support for democracy in post-communist Europe. Comparative Political Studies, 28(4), 553-581.

Morgenbesser, L. (2016). The autocratic mandate: Elections, legitimacy and regime stability in Singapore. The Pacific Review, 1-27.

Omelicheva, M. Y. (2016). Islam and power legitimation: Instrumentalisation of religion in Central Asian States. Contemporary Politics, 22(2), 144-163.

Rigby, T. H., \& Fehér, F. (1982). Political legitimation in communist states. London: Macmillan and St Antony's College, Oxford.

Rose, R. (1995). Mobilizing demobilized voters in post-communist societies. Party Politics, 1(4), 549-563.

Rothschild, J. (1977). Observations on political legitimacy in contemporary Europe. Political Science Quarterly, 92(3), 487-501.

Ryabchuk, A. (2014). Right revolution? Hopes and Perils of the Euromaidan Protests in Ukraine. Debatte: Journal of Contemporary Central and Eastern Europe, 22(1), 127-134.

Sandby-Thomas, P. (2014). How do you solve a problem like legitimacy? Contributing to a new research Agenda. Journal of Contemporary China, 23(88), 575-592.

Sapsford, R., \& Jupp, V. (2006). Data collection and analysis. London: SAGE.

Saurugger, S. (2007). Democratic 'misfit'? Conceptions of civil society participation in France and the European Union. Political Studies, 55(2), 384-404.

Scharpf, F. (1997). Economic integration, democracy and the welfare state. Journal of European Public Policy, 4(1), 18-36.

Scharpf, F. (1998). Interdependence and democratic legitimation. MPIfG Working Paper, 98(2), Retrieved from http://hdl.handle.net/10419/41689.

Scharpf, F. (2003). Problem-solving effectiveness and democratic accountability in the EU (MPIfG working paper). Retrieved from http://www.econstor.eu/handle/10419/41664.

Schmidt, V. A. (2013). Democracy and legitimacy in the European Union revisited: Input, output and 'throughput'. Political Studies, 1-21.

Stiftung, B. (2016). Transformation Index BTI. Retrieved from http://www.bti-project.org/index/statusindex/.

Tyler, T. R., \& Caine, A. (1981). The influence of outcomes and procedures on satisfaction with formal leaders. Journal of Personality and Social Psychology, 41(4), 642-655.

Tyler, T. R. (2001). The legitimacy of institutions and authorities. In J. T. Jost \& B. Major (Eds.), The psychology of legitimacy: Emerging perspectives on ideology, justice, and intergroup relations (pp. 416436). Cambridge: Cambridge University Press.

Tyler, T. R. (2003). Procedural justice, legitimacy, and the effective rule of law. Crime and Justice: $A$ Review of Research, 30, 283-357.

Van der Toorn, J., Tyler, T. R., \& Jost, J. T. (2011). More than fair: Outcome dependence, system justification, and the perceived legitimacy of authority figures. Journal of Experimental Social Psychology, 47(1), 127-138.

Von Soest, C., \& Grauvogel, J. (2015). How do non-democratic regimes claim legitimacy? Comparative insights from post-soviet countries (GIGA Working Paper, 277). Retrieved from http://www.gigahamburg.de/de/publication/how-do-non-democratic-regimes-claim-legitimacy-comparative-insi ghts-from-post-soviet.

Von Haldenwang, C. (2017). The relevance of legitimation - a new framework for analysis. Contemporary Politics. doi:10.1080/13569775.2017.1304322

Von Soest, C., \& Grauvogel, J. (2017). Identity, procedures and performance: How authoritarian regimes legitimize their rule. Contemporary Politics. doi:10.1080/13569775.2017.1304319

Way, L. A. (2005). Authoritarian state building and the sources of regime competitiveness in the fourth wave: The cases of Belarus, Moldova, Russia, and Ukraine. World Politics, 57(2), 231-261.

Weatherford, M. S. (1992). Measuring political legitimacy. American Political Science Review, 86(1), 149-166.

Weber, M. (1947). From max weber: Essays in sociology. London: Routledge \& Kegan Paul LTD. 
Weber, M. (1978). Economy and society: An outline of interpretive sociology. Berkeley: University of California Press.

White, S. (1986). Economic performance and communist legitimacy. World Politics, 38(3), 462-482.

White, S., \& Kryshtanovskaya, O. (2011). Changing the Russian electoral system: Inside the black box. Europe-Asia Studies, 63(4), 557-578.

Wilson, K. (2009). Party-system reform in democracy's Grey Zone: A response to Moraski. Government and Opposition, 44(2), 188-207. 